\title{
The role of dispensaries in community health care in the Kainji Lake area of Nigeria
}

\author{
E. O. ADEKOLU-JOHN \\ From the Kainji Lake Research Institute, New Bussa
}

SUMMARY Dispensaries have been the most common providers of health services in the Kainji Lake rural area of Nigeria and the only form of health facility in this area. A survey of the working conditions of the dispensary assistants showed that $70 \%$ of the respondents are already frustrated because of lack of support, supervision, and prospects for further training. A proposal is made for further training of the dispensary assistants and for improving their conditions of service. The seasonal distribution of the common diseases (malaria, gastroenteritis, chest infections, skin diseases, gonorrhoea, and schistosomiasis) shows that infection follows the pattern of rainfall, and that there are some differences between the pattern of these common diseases and the common ailments reported by the villagers located away from the dispensaries. A suggestion is made for the introduction of primary health workers to meet the health needs of the villagers, $60 \%$ of whom have not received dispensary services.

Throughout the period of physical resettlement $(1962-70)$ and up to the present day, the dispensaries have been the most numerous providers of health services in the rural area of Kainji Lake. Although there are three hospitals, one health centre, and four maternal and child health centres, the dispensaries will continue to provide most of the health care needed in the rural areas because of their locations. For any basic health service to be successful, therefore, the role of the dispensaries as health providers needs to be examined. This paper studies the functioning of the dispensaries in the Kainji Lake area and makes recommendations to improve their utility.

\section{BACKGROUND}

The Kainji Lake $\left(1250 \mathrm{~km}^{2}\right)$ is situated between latitude $9^{\circ} 50^{\prime}$ and $10^{\circ} 57^{\prime}$ north and longitude $4^{\circ} 25^{\prime}$ and $4^{\circ} 45^{\prime}$ east. The area also includes places where the resettled population live, close to the lake and the River Niger. In these areas, the most distant resettled community is New Bussa, about $20 \mathrm{~km}$ from the lake, and Tungan Tsamiya is the uppermost village, close to the River Niger about $40 \mathrm{~km}$ from where the river joins the lake.

Before 1967, the Kainji Lake area was governed by the Northern Regional Government and native authorities. When more states were created in 1967 and 1976, the area came under three different states and divisional governments. In 1977 it was further divided among three local government areas, Borgu on the western side, Yauri on the upper third of the eastern side, and Magama on the remaining third.

Three types of villages could be distinguished-the resettlement villages, the host villages, and the fishing villages. The characteristics of these villages have been described (Adekolu-John, 1979).

Along the western side of the lake area, one road was constructed from Wawa to Rofia to replace the one inundated by the lake. On the eastern side, no road was constructed during the formation of the lake. At present there are few roads, and the tracks are impassable during the rainy seasons. Access to most villages round the lake is by footpaths, tracks, or the lake.

\section{Method}

All the dispensaries were visited in August 1974 to assess the facilities and the procedure for reporting diseases by the dispensary assistants. For the purposes of this paper, a dispensary assistant is a primary school leaver who spent three years in a medical auxiliary training school studying human anatomy and physiology, pharmacology, basic nursing, laboratory techniques, preventive medicine, public health, and dispensary routine. The dispensary data for the preceding year were collected and analysed to discover the commoner diseases. Subsequently two questionnaires were designed. The 
purpose of the first was to collect information from dispensary assistants in the rural areas on their conditions of service, experience on the job, attitude to the environment in which they worked, type of data collected, official and unofficial duties, and the extent of the coverage by each dispensary of villages outside their locations. The dispensaries in New Bussa and Yelwa were not included in this study, and the two dispensaries at Agwara, one missionary and one local government, were regarded as serving the same populations and considered as one.

The second questionnaire was designed to collect information from heads of households in each of the villages outside the dispensary locations on the use of the nearby dispensaries and on what ailments take the people to the dispensaries.

\section{Results}

Table 1 shows the health facilities existing before the impoundment of Kainji Lake in 1968 and the facilities in 1978. There were just over twice as many different health facilities in $\mathbf{1 9 7 8}$ as in the previous period. In both periods, the dispensaries were the most numerous providers of health care. In terms of growth rates, the dispensaries grew at the same rate as the maternal and child health centres but more slowly than public health units. In both periods there were more facilities on the western than on the eastern side of the lake.

The relative distribution of the seven major diseases in the eight dispensary locations is shown in Table 2. Malaria was highest in all, followed by gastroenteritis, cough, pneumonia, gonorrhoea, skin infections, and schistosomiasis. The analysis of variance of the common diseases, using the dispensary locations as a criterion, was highly significant at both $5 \%$ and $1 \%$ levels of significance. The Figure shows the monthly distribution of five of the seven most common diseases. For all the diseases, infection begins to increase from April until October and is heaviest in November.

Ten dispensary assistants between the ages of 20 and 60 were interviewed. Eight were aged between

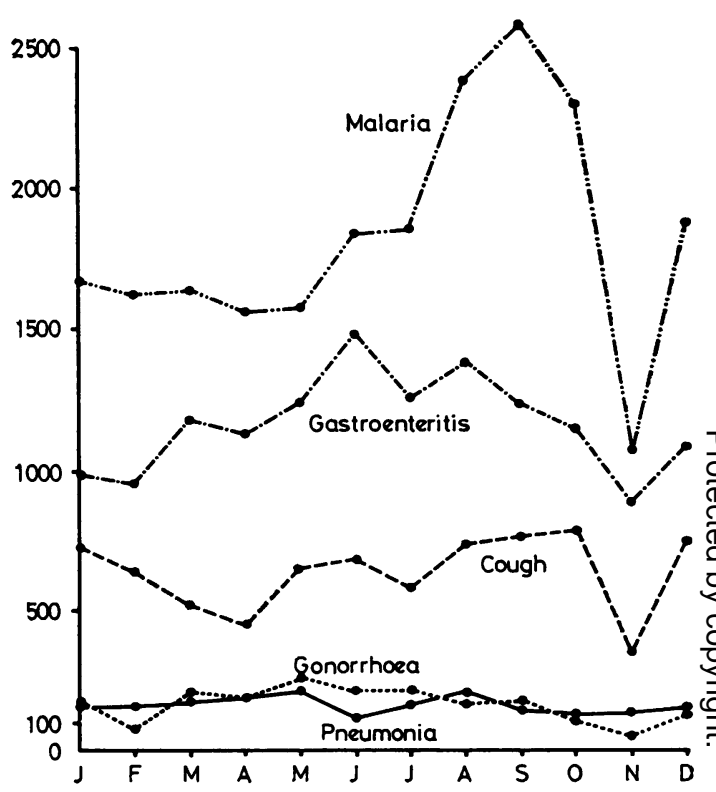

Figure Seasonal patterns of five major diseases.

Table 1 Health care facilities in the Kainji Lake area before 1968 and in 1978

\begin{tabular}{|c|c|c|c|c|c|c|c|}
\hline \multirow[b]{2}{*}{ Types of institution } & \multicolumn{3}{|c|}{ Before 1968} & \multicolumn{3}{|c|}{1978} & \multirow{2}{*}{$\begin{array}{l}\text { Ratio } \\
1978 / 1968\end{array}$} \\
\hline & No. & West bank & East bank & No. & West bank & East bank & \\
\hline Hospitals & 2 & 1 & 1 & 3 & 2 & 1 & 1.5 \\
\hline Health centres & - & - & - & 1 & - & 1 & - \\
\hline Maternal and child health centres & 2 & 2 & - & 4 & 4 & - & $2 \cdot 0$ \\
\hline Public health units & 2 & 1 & 1 & 6 & 5 & 1 & 3.0 \\
\hline Dispensaries & 7 & 4 & 3 & 13 & 7 & 6 & 1.8 \\
\hline Total & 13 & 8 & 5 & 27 & 18 & 9 & $2 \cdot 1$ \\
\hline
\end{tabular}

Table 2 Relative distribution in percentages of seven major diseases in eight dispensary locations

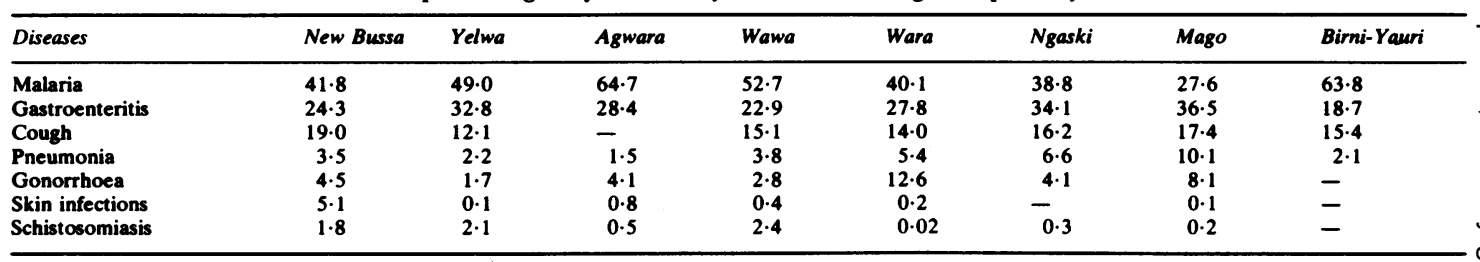


Table 3 The coverage of the dispensaries outside their locations

\begin{tabular}{|c|c|c|c|c|c|}
\hline $\begin{array}{l}\text { Location of } \\
\text { dispensaries }\end{array}$ & $\begin{array}{l}\text { No. of } \\
\text { villages served }\end{array}$ & $\begin{array}{l}\text { Maximum distance } \\
\text { covered (miles) }\end{array}$ & Mean distance & $S D$ & Total miles covered \\
\hline $\begin{array}{l}\text { Wawa } \\
\text { Ngaski } \\
\text { Birni-Yauri } \\
\text { Wara } \\
\text { Auna } \\
\text { Rofia } \\
\text { Shagunu } \\
\text { Mago } \\
\text { Agwara } \\
\text { Nasarawa }\end{array}$ & $\begin{array}{l}7 \\
8 \\
8 \\
7 \\
8 \\
6 \\
8 \\
8 \\
8 \\
7\end{array}$ & $\begin{array}{r}16 \\
8 \\
22 \\
5 \\
12 \\
15 \\
17 \\
9 \\
15 \\
17\end{array}$ & $\begin{array}{r}10 \cdot 2 \\
4 \cdot 5 \\
8 \cdot 0 \\
3 \cdot 0 \\
5 \cdot 1 \\
7 \cdot 0 \\
7 \cdot 6 \\
6 \cdot 7 \\
6 \cdot 6 \\
7 \cdot 9\end{array}$ & $\begin{array}{l}4.91 \\
1.98 \\
6 \cdot 35 \\
1 \cdot 15 \\
3.91 \\
4 \cdot 05 \\
4 \cdot 75 \\
1 \cdot 75 \\
4 \cdot 27 \\
5 \cdot 67\end{array}$ & $\begin{array}{l}71 \\
36 \\
64 \\
21 \\
40 \cdot 5 \\
42 \\
61 \\
54 \\
53 \\
55\end{array}$ \\
\hline
\end{tabular}

25 and 35 . Seven enjoyed free housing and five had loans of vehicles. Nine out of 10 had had less than five years' experience since qualifying. Seven were unhappy where they worked and were going to ask to be transferred elsewhere.

The dispensary assistants perform three types of duties-diagnosis and treatment of all cases, treatment of leprosy, and health inspections. They also take part in mass immunisation and census enumeration when required. They collect reports weekly for infectious diseases, and monthly for leprosy and morbidity data. Table 3 shows the coverage of the dispensaries outside their locations. The dispensaries at Ngaski (serving eight villages), at Wara (seven villages) and at Mago (eight villages) have smaller distances to cover and also serve nearby villages.

Table 4 shows the age, sex, and occupation of 1216 heads of households interviewed in 43 of the 75

Table 4 Age, sex, and occupation of heads of households in 43 villages

\begin{tabular}{lrc}
\hline $\begin{array}{l}\text { Age group } \\
\text { (years) }\end{array}$ & Men & Women \\
\hline $15-19$ & 5 & 2 \\
$20-24$ & 36 & - \\
$25-29$ & 78 & 1 \\
$30-34$ & 210 & 1 \\
$35-39$ & 196 & 3 \\
$40-44$ & 182 & 6 \\
$45-49$ & 90 & 6 \\
$50-54$ & 122 & 2 \\
$55-59$ & 61 & 2 \\
$60-64$ & 88 & 1 \\
$65-69$ & 34 & 2 \\
Not stated & 88 & \\
& & - \\
Total & 1190 & 26 \\
\hline Occupations & 1316 & - \\
Farming & 56 & - \\
Trading & 36 & - \\
Fishing & 98 & - \\
Others* & & \\
Total & 126 & - \\
\hline Incs & 519 & - \\
\hline
\end{tabular}

- Includes multiple occupations. villages included in the survey. Poor and inaccessible roads and foot tracks made it difficult to cover all the villages. Ninety-five per cent of the heads of households were men, most of them farmers.

Table 5 shows the numbers and percentages of people who attended or did not attend the dispensaries nearest to their villages, and analyses the other forms of treatment available to non-attenders. About $60 \%$ of the people had not attended their local dispensaries for medical attention. Further analysis shows, however, that a high proportion of people in villages five to six miles away and more than 12 miles away did attend dispensaries. Of the $60 \%$ who did not attend local dispensaries, more than half did not receive any treatment when they were sick and about $26 \%$ received traditional forms of treatment.

The common ailments that send villagers to the local dispensaries are shown in Table 6 . These are mainly malaria, body and joint pains, gastroenteritis, skin diseases, conjunctivitis, and measles.

\section{Discussion}

The resettlement exercise in Kainji has been acclaimed as the most painless exercise of its kind but it failed in excluding health matters from the resettlement operations. The reason for this failure was that, unlike the Volta Lake area of Ghana, the Kainji Lake area of Nigeria was not the responsibility of a single developing authority. As a result, health problems and development were left to the different state governments, local governments, and interested organisations. This has created an uneven distribution of health facilities (Adekolu-John, 1979). The growth of different health institutions shown in Table 1 is therefore a reflection of the relative political importance ascribed to the different towns and villages in the Kainji Lake area by their respective state and local authorities, rather than an indication of the health problems as such. Although the dispensaries grew at the same rate as the maternal and child health centres, the growth of these centres was limited to the big towns, New Bussa and Yelwa, 
Table 5 Use of health services by distance of village from a dispensary

\begin{tabular}{|c|c|c|c|c|c|c|c|}
\hline \multirow[b]{2}{*}{$\begin{array}{l}\text { Distance } \\
\text { (miles) }\end{array}$} & \multirow[b]{2}{*}{$\begin{array}{l}\text { No. of } \\
\text { respondents }\end{array}$} & \multicolumn{6}{|c|}{ Per cent using health services } \\
\hline & & $\begin{array}{l}\text { Village } \\
\text { dispensary }\end{array}$ & $\begin{array}{l}\text { Traditional } \\
\text { healers }\end{array}$ & $\begin{array}{l}\text { Self } \\
\text { medication }\end{array}$ & $\begin{array}{l}\text { Other } \\
\text { forms }\end{array}$ & $\begin{array}{l}\text { None or } \\
\text { never sick }\end{array}$ & $A \| l$ \\
\hline $\begin{array}{l}0-2 \\
3-4 \\
5-6 \\
7-8 \\
9-10 \\
11-12 \\
12+ \\
\text { All distances }\end{array}$ & \begin{tabular}{r|}
203 \\
283 \\
140 \\
251 \\
148 \\
88 \\
103 \\
1216
\end{tabular} & $\begin{array}{l}38 \\
45 \\
71 \\
30 \\
23 \\
22 \\
56 \\
40\end{array}$ & $\begin{array}{r}18 \\
14 \\
2 \\
13 \\
27 \\
19 \\
18 \\
15\end{array}$ & $\begin{array}{r}- \\
-2 \\
3 \\
5 \\
- \\
2\end{array}$ & $\begin{array}{r}10 \\
6 \\
4 \\
-5 \\
3 \\
-5\end{array}$ & $\begin{array}{l}34 \\
33 \\
22 \\
54 \\
40 \\
54 \\
26 \\
38\end{array}$ & $\begin{array}{l}100 \\
100 \\
100 \\
100 \\
100 \\
100 \\
100 \\
100\end{array}$ \\
\hline
\end{tabular}

- Includes prayer, incantations, and drinking ordinary water.

Table 6 Common ailments in the villages

\begin{tabular}{|c|c|c|c|c|c|c|c|c|}
\hline \multirow[b]{2}{*}{ Diagnosis } & \multicolumn{7}{|c|}{ Distance from dispensary (miles) } & \multirow{2}{*}{$\begin{array}{l}\text { Total no } \\
\text { of cases }\end{array}$} \\
\hline & 0.2 & $3-4$ & $5-6$ & $7-8$ & 9.10 & $11-12$ & $12+$ & \\
\hline $\begin{array}{l}\text { Malaria } \\
\text { Body or joint pains } \\
\text { Gastroenteritis } \\
\text { Skin diseases } \\
\text { Conjunctivitis } \\
\text { Measles } \\
\text { Chest infections } \\
\text { Leg ulcers } \\
\text { Leprosy } \\
\text { Snake bite } \\
\text { Other conditions } \dagger \\
\text { ALL CONDITIONS }\end{array}$ & $\begin{array}{r}33 \\
44 \\
31 \\
9 \\
13 \\
-\quad 2 \\
3 \\
-\quad 7 \\
143\end{array}$ & $\begin{array}{r}55 \\
36 \\
46 \\
7 \\
4 \\
- \\
- \\
3 \\
3 \\
2 \\
21 \\
177\end{array}$ & $\begin{array}{r}35 \\
32 \\
16 \\
4 \\
2 \\
9 \\
1 \\
1 \\
2 \\
1 \\
30 \\
133\end{array}$ & $\begin{array}{r}51 \\
29 \\
32 \\
6 \\
3 \\
2 \\
1 \\
- \\
- \\
1 \\
11 \\
136\end{array}$ & $\begin{array}{r}35 \\
31 \\
11 \\
2 \\
5 \\
- \\
- \\
- \\
1 \\
16 \\
101\end{array}$ & $\begin{array}{l}11 \\
\overline{10} \\
1 \\
- \\
- \\
- \\
- \\
-1 \\
23\end{array}$ & $\begin{array}{l}22 \\
15 \\
19 \\
- \\
\overline{3} \\
5 \\
- \\
\overline{12} \\
76\end{array}$ & $\begin{array}{r}242 \\
187 \\
165 \\
29 \\
27 \\
14 \\
9 \\
7 \\
6 \\
5 \\
98 \\
789\end{array}$ \\
\hline
\end{tabular}

t None more than five cases.

as was also the case with hospitals and public health units. The growth of the dispensaries took place only in the rural areas. The geographical distribution of the dispensaries before impoundment and in 1978 (Table 1) shows that growth occurred equally on both sides of the lake area, in spite of the fact that the area had been governed by different administrative authorities at different times.

The high prevalence of malaria in all dispensary locations is in keeping with the holoendemic status of the disease in this area (Waddy, 1972), with local streams and the Kainji lake providing a suitable habitat for the breeding of mosquitoes. The high proportion of gastroenteritis, chest infections, and schistosomiasis can be explained by the lack of sanitation facilities in the area and by poor personal hygiene (Adekolu-John, 1979). However, the relative importance of schistosomiasis as presented in Table 2 was underestimated when compared with Teesdale's findings(1971) where field surveys of urine were positive in almost $100 \%$ of the age group 9-13 examined.

Rainfall in Kainji Lake area commences in April, with intensity increasing in early October. Subsequently the intensity decreases, becoming lowest in November, December, and January. The seasonal distribution of the important diseases (Figure) seems to follow the rainfall pattern.

Seventy per cent of the dispensary assistants were not happy because of frustration due to being forgotten in their stations, poor prospects for further training, frequent drug shortages, and no mileage claims when they extended their health inspections and health education to neighbouring villages. These frustrations have caused a drift of these trained staff from their rural stations to urban areas to seek better job opportunities. This explains why $90 \%$ of the dispensary assistants have less than five years' experience. It is necessary for local governments to introduce bush and mileage allowances for the dispensary assistants. I propose that a curriculum for specialist training in dispensary medicine should be introduced. In this curriculum, further training in environmental health and health education, diagnosis and treatment of disease, and control of leprosy should be included. Dispensary assistants with a minimum of three years' experience should be encouraged to train in any of the above disciplines. The period of training should not be more than one year. 
To improve further the efficiency and coverage of the dispensaries, another category of staff with lower qualifications than the dispensary assistants needs to be introduced into the system. Such staff should have basic primary school education with three to six months' training in the rudiments of health care. In 1977 a training for primary health workers in basic health data collection, environmental sanitation, and health education was organised by the Kainji Lake Research Institute, New Bussa. Twenty-seven primary school leavers from four local governments (Borgu, Yauri, Mariga, and Magama) took part in the course, which lasted three months. The successful candidates were posted to urban dispensaries to gain practical experience for three months, after which they were posted as primary health workers to some of the rural dispensaries. These categories of staff will be suitable to handle the health care of villages far away from the dispensary under the supervision of the dispensary assistants if supported by the local governments. It is envisaged that these categories of staff will eventually be sponsored by their local governments for the medical auxiliary course to qualify as dispensary assistants.

The weekly count of infectious diseases and monthly leprosy and morbidity data cannot be related to some vital demographic parameters like age, sex, and occupation. The reports therefore cannot provide all the indices that would point to the state of health in the rural areas. Since the dispensaries are the only source of information on the health of the rural people, it is necessary for dispensary reports to be modified to classify diseases according to age, sex, and occupations.

The proportion of villagers who attended the local dispensaries is generally low (Table 5). However, no trend can be established between the villages served and the distances of villages from the dispensaries. In the 5 to 6 mile and $12+$ miles distance groups of villages, where the proportion attending is high, it was discovered that these villages had accessible roads and tracks to the dispensaries. Clearly, good roads would influence the use of the dispensaries by villagers outside dispensary locations.

The common ailments that take people to the local dispensaries seem to differ from the actual dispensary reports (Adekolu-John, 1979) in that chest infections, gonorrhoea, and schistosomiasis are more frequently diagnosed than body and joint pains, conjunctivitis and measles. It is possible that these diseases are more frequently reported in areas with dispensaries. For dispensary reports to be comprehensive, disease reports should include information on where the patients live who come to the dispensaries for treatment. This would help in detecting the source of any possible outbreak of disease and indentifying diseases peculiar to particular villages.

Frequent visits to any of the dispensaries show that patient attendance is highest on market days, drugs are in short supply, and there are no storage facilities for anti-snake venom to treat cases of snake bite or for vaccines. To achieve the maximum utilisation of the dispensaries, supplies of drugs should always be available on market days, and cold storage facilities should be provided.

At present most of the dispensaries are sponsored by local governments, with little or no involvement by state governments. The impact of local government on the health of the rural population can be measured only by the improvement in the organisation and administration of dispensary services in Kainji Lake area.

I thank my field staff for their patience during the collection and analysis of the data, and Mr. E. A. Ekwemalor, Research Officer, Kainji Lake Research Institute, New Bussa, for statistical analysis of the data. Permission to publish this paper was granted to me by the Director of the Kainji Lake Research Institute, New Bussa.

Reprints from E. O. Adekolu-John, Kainji Lake Research Institute, PMB 666, New Bussa, Kwara State, Nigeria.

\section{References}

Adekolu-John, E. O. (1979). A communication of health and development in the Kainji Lake area of Nigeria. Acta Tropica, 36, 91-102.

Teesdale, C. (1971). Report on the human helminthic infections in the Lake Kainji area. WHO: Geneva.

Waddy, B. B. (1972). Health component in the Kainji Lake Research Project. WHO: Geneva. 